\title{
23 \\ Sydisdans: A New Traditional Dance in Sapmi
}

\author{
Nils-Jonas Persson
}

\section{Introduction by Åsa Virdi Kroik}

I do not remember when I first heard of sydisdans. I just remember that suddenly it was there and every Saami knew what it was. In the inland of Scandinavia and Sapmi, where I grew up, events are often arranged in the villages. A local band is hired for one night and people gather from the nearby villages to dance. People may need to travel 100-200 kilometres or more to such events, but the motivation to attend is often very high among local people. Youngsters without a driver's licence or car somehow manage to find their way to the location and back again. South Saami have been dancing with their Scandinavian neighbours at such dance events for generations, and they have developed dances together and integrated influences from the outside. Time for dancing is often integrated in Saami events, like important political meetings or sport competitions, although no competition in dance has ever taken place in a Saami context as far as I know. It was in such Saami contexts that sydisdans developed.

In 2015, when the South Saami joiker and singer Jon Henrik Fjällgren almost won the popular Swedish national song contest, Melodifestivalen, he took the dancers Nils-Jonas Person and Jannie Staffansson on stage with him to perform a sydisdans. Something happened. From being a concept that every Saami (but hardly any non-Saami) was familiar with, 
sydisdans became a word on everybody's lips. The following text is edited from an interview that I conducted, together with Hiroshi Maruyama and Gerald Roche, with Nils-Jonas Persson about sydisdans.

$$
\star \star \star
$$

Sydisdans-southern dance-is danced by couples. It's almost like a mixture of foxtrot and swing. The best way to dance it is when there's a lot of speed in the music, a lot of movement. Most of the time, sydisdans is a happy dance. It's never sad. But, sometimes, it can be a little more affectionate, a little more sensual. But mostly it is happy. So to me, that's what a sydisdans is all about - good fun. It makes people happy, and you can be social. The music for a sydisdans can be anything. It doesn't have to be joik. It could be country, hip-hop, reggae, or whatever. It works with everything.
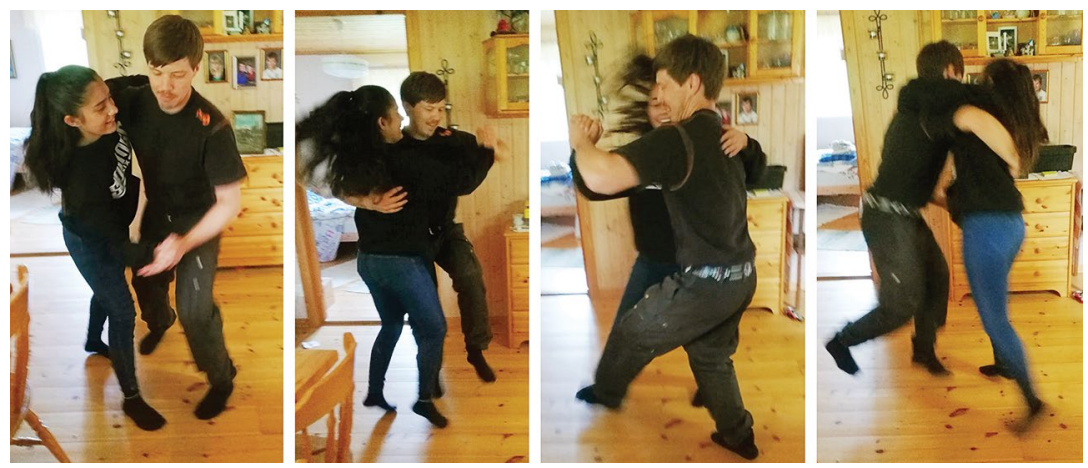

Figure 19. Jenny Virdi Kroik and David Kroik dancing the sydisdans at a family gathering. The collage gives a sense of the movement of the dance.

Source. Photographed by Åsa Virdi Kroik, Buarkantjahke/Borgafjäll, July 2018.

I don't think anyone knows the origins of the dance, but a rumour says it began in southern Norway, or the middle of Norway. But that's not really known for sure-I guess you could say it's more of a myth. My friend did some research on the topic, and that was the closest she came. And although this dance is new, Saami people probably did have some sort of traditional dance in the past. It might have been part of their shamanic tradition, but it vanished because people lost the deep connection to their shamanic religion after Christianity came and, sort of, made it disappear. 
My first encounter with a sydisdans was at a wedding here in Amarnäs, where a Saami girl taught me to dance it. Ever since that day, I have danced every single chance I get. You can't really learn a sydisdans from a book. There's no school for it. You learn it on the dance floor, with your friends. And since you have to dance with emotion, everyone dances it differently. They have their own style and moves—different spins, jumps and lifts. It depends on the person (see Figure 19).

When we danced on television for Jon Henrik's performance on Melodifestivalen, our performance was largely improvised, but they did give us some directions. So, when we danced on the TV show, they told us that we had to be at specific places at specific times during the song, but they couldn't direct what types of steps or spins we did or anything like that. We were really free in the dancing, as long as we were in the right place at the right time.

Before the performance, I had danced with a particular girl a couple of times-we had met each other at gatherings with Jon Henrik and others. Jon Henrik knows us both. The girl's name is Jannie Staffansson. I have a bit of a name in Sapmi for being a good dancer, so Jon just called me and asked if I wanted to join him. And as for Jannie, she and Jon grew up together, so he knew she was a good dancer. That was my first time dancing on TV, so it was quite nerve-wracking. But it worked out well. Before that, I'd been to ordinary dances in pubs and so on, but nothing like this. The only thing that comes close is that the same girl and I had a clip on YouTube a few years ago (Melodifestivalen 2015).

As for my identity - this dance hasn't made much of a difference to my identity. That's because I already had a very solid grounding in my identity, with the reindeer and so on. But I know that, especially in the southern parts of Sapmi, dancing is very important for people's identity. It's almost as if you are expected to dance. Once you're 10 years old, you need to learn how to dance if you come from the southern part of Sapmi. In the northern part, they don't dance as much. So, for the northern part, the dance doesn't have much connection to identity, but in the southern part there's a connection and there's an expectation that you should be a good dancer.

Now, however, I think the sydisdans is starting to become distinctive of Saami culture. I think that in the future we will see more and more of it at special occasions. A couple of years ago, I published some brief 
instructions about how to dance sydisdans, together with a woman from Jokkmokk. We published that in the Saami magazine Nuorat, which is produced by and published for young Saami. After we published that article, I noticed a few changes. For example, some people called me and asked if I could hold a class, or teach them. And after that, I also was a leader for a confirmation. ${ }^{1}$ And, then we had a lot of staff classes for various businesses. So, a couple of years after the publication of the journal article, I had about 70 youths who came and danced. Now they've really grown up and they still know how to dance. In fact, young people really like the dance - they're really excited about it and they want to learn more about it. So, I think the dance is spreading and its popularity is growing.

Since the TV performance, the reaction has been really good. I vanished for a while immediately after the performance, because I went to see my girlfriend in Norway, and I am not known by so many people there. When I got home to Sweden, the whole thing had settled down, so I missed the immediate reaction after it. But, generally, the opinion has been that it was very good. It was good that we represented Sapmi so well. It felt good to share it with people.

I think the popularity of the dance is somewhat connected to growth in other areas of Saami culture. For example, in my area, people didn't joik openly until recently. My grandfather didn't speak the Saami language, even though he knew it, because he got beaten and told that he was not allowed to speak it. They were also told not to joik. So it is only, perhaps, 30 or 40 years ago that children began to be allowed to speak the language at school, and public opinion changed so that the language became more or less accepted. So joiks have only very recently returned, perhaps in the last 10 or 20 years. For a lot of people, the sydisdans is connected to their identity and self-respect and their general feeling about their roots. But, for me, and for others too, it is something modern-something to be proud of because we have it and no other culture has it. So, on the one hand, the popularity of the dance is connected to the return of traditions, but on the other hand, it is also very modern. I think it's a little bit of both.

1 The Swedish church organises schools or camps for teenagers to learn more about Christianity and to confirm their baptism. It is very common to baptise newborns in Scandinavia and in Sapmi, and it is a strong tradition for those who are baptised to make their confirmation of those vows as adolescents. Among the Saami, it is common to participate in such camps, and since about the 1980s, there are also special camps only for Saami youth. Apart from priests, there are also lay leaders at the camps, and in the Saami confirmation camps, the leaders are recruited from among young Saami adults. 
I think the dance is also a way to reach out to Swedish people and to show them that we exist, that we have traditions, and that we really want to talk about them, and to show people our culture. Even in my neighbouring village, about 200 kilometres away, they don't even know what a Saami is. So, the dance is a way to reach out to the general public and let them know that we exist.

\section{Reference}

Melodifestivalen. 2015. Jon Henrik Fjällgren - Jag Är Fri. Online: www.youtube. com/watch?v=3tfvV-5Wq4w (accessed 27 July 2018).

Nuorat. Online: www.nuorat.se (accessed 9 July 2018). 
This text is taken from Indigenous Efflorescence: Beyond Revitalisation in Sapmi and Ainu Mosir, edited by Gerald Roche, Hiroshi Maruyama and Åsa Virdi Kroik, published 2018 by ANU Press, The Australian National University, Canberra, Australia.

doi.org/10.22459/IE.2018.23 